\title{
Pemahaman Orang Tua Mengenai Gizi Anak
}

\author{
Aida Ayu Fitriana \\ STKIP Modern Ngawi \\ J1. Ir Soekarno (Ring Road Barat) Kabupaten Ngawi \\ aidaayufitriana37@gmail.com
}

\begin{abstract}
Abstrak
Orang tua memiliki peranan penting dalam pemenuhan asupan gizi anak, sehingga harus paham kebutuhan nutrisi anak makanan yang baik dan makanan yang tidak baik tidak terpengaruh gaya hidup yang serba instan. Metode yang digunakan dalam penelitian ini adalah deskriptif kuantitatif. Penelitian ini dilakukan di Desa Klempun Kecamatan Ngraho Kabupaten Bojonegoro. Jumlah orang yang diwawancara adalah 20 orang dengan ketentuan memiliki anak usia PAUD. Berdasarkan hasil penelitian yang telah dilakukan dan analisis data angket maka secara umum dapat disimpulkan bahwa pemahaman gizi oleh orang tua di Pos PAUD Tangkas Desa Klempun Kecamatan Ngeraho Kabupaten Bojonegoro bervariasi tergantung sub variabel yang ditanyakan. Diharapkan kepada orang tua untuk selalu belajar dalam memahami gizi.

Kata Kunci: Orang tua, Gizi, PAUD
\end{abstract}

\section{PENDAHULUAN}

Gizi adalah unsur yang terkandung di dalam makanan yang dapat memberikan suatu manfaat bagi tubuh yang ketika mengkomsumsinya dapat menjadi sehat (Pratiwi \& VAV, 2014). Dapat diketahui bahwa makanan yang kita makan harus mengandung unsur sehat misalnya makanan yang mengandung protein, karbonhidrat, vitamin, lemak dan mineral. Selain itu gizi merupakan suatu bagian dari proses kehidupan dan proses tumbuh kembang anak,maka sehingga pemenuhan gizi anak harus akurat turut menentukan kualitas untuk tumbuh kembang dan sebagai sumber daya manusia untuk dimasa yang akan datang. Pemenuhan gizi anak harus lebih diperhatikan karen gizi yang dikonsumsi oleh anak turut menentukan kualitas pertumbuhan dan perkembangan anak. Asupan gizi anak memiiki peranan penting dalam tumbuh kembang anak agar anak dapat tumbuh dan berkembang secara optimal. Pemenuhan gizi yang seimbang pada anak juga dapat mempengaruhi kecerdasan otak anak sehingga dapat dijadikan pembekalan awal anak untuk dimasa yang akan datang.

Gizi seimbang merupakan konsep nutrisi yang masuk pas, tidak kurang sehingga menyebabkan tidak kurus dan stunting serta tidak berlebihan sehingga menyebabkan obesitas. Gizi seimbang adalah makanan yang dikonsumsi oleh individu sehari-hari yang beraneka ragam dan memenuhi 5 kelompok zat gizi dalam jumlah yang cukup, tidak berlebihan dan tidak kekurangan (Dirjen BKM, 2002). 
Menu seimbang menu yang terdiri dari beraneka ragam makanan dengan jumlah dan proporsi yang sesuai, sehingga memenuhi kebutuhan gizi guna pemeliharaan dan perbaikan sel-sel dalam tuubuh dan proses kehidupan serta pertumbuhan dan perkembangan (Almatsier, 2002).

Orang tua memiliki peranan penting dalam pemenuhan asupan gizi anak, sehingga harus paham kebutuhan nutrisi anak makanan yang baik dan makanan yang tidak baik tidak terpengaruh gaya hidup yang serba instan serta iklaniklan produk makanan anak yang menjanjikan hal yang berlebihan. Seiring dengan berkembangnya zaman pada saat ini, pada zaman dimana serba instan begitu juga dengan makanan yang serba instan dalam kemasan yang begitu digemari oleh anak pada zaman sekarang. Walaupun anak-anak suka makanan yang sedemikian hingga membuat anak menjadi semakin malas dan tidak mau memakan makanan yang sehat seperti makan sayur dan buah, tapi sebagai orang tua dapat mencegah dan memberi penjelasan agar kebiasaan buruk itu tidak menjadi kebisaan yang berkelanjutan dalam jangka waktu yang berkelanjutan untuk selanjutnya. Maka sebagai orang tua harus mengetahui dampak buruk atau negatif jika anak terus mengkomsumsi makanan yang serba instan bagi perkembangan atau kesehatan anak usia dini. Pemahaman gizi dapat dipelajari orang tua melalui media internet, namun pemahaman orang tua mengenai literasi digital juga harus sesuai karena mempengaruhi ketahanan keluarga (Laksono et al., 2019). Dengan adanya pemahaman orang tua akan kebutuhan gizi anak yang benar maka pola asupan gizi yang akan diberikan oleh orang tua akan sesuai dengan kebutuhan anak,sehingga anak dapat berkembang secara optimal sesuai dengan potensi yang dimilikinya. Penelitian ini dilakukan untuk meningkatkan pemahaman orang tua akan kebutuhan gizi anak, yang sebelumnya banyak orang tua yang kurang memahami betul akan manfaat mkanan gizi yang sehat misalnya manfaat sayur dan buah hanya bermanfaat sebagai kekebalan tubuh saja. Hingga menjadi paham bahwa manfaat buah dan sayur tidak hanya sebagai kekebalan tubuh saja bahkan dapat berperan penting bagi tubuh sang anak salah satu manfaatnya ialah dapat mempengaruhi kecerdasan otak anak dan masih banyak lagi manfaat yang berdampak pada anak jika anak terpenuhi kebutuhan akan gizi yang seimbang.dan penelitian ini juga untuk meningkatkan pemahaman orang tua akan dampak apa saja yang dialami oleh anak dimasa yang akan datang ketika anak tidak mendapatkan asupan gizi yang seimbang sesui dengan kebutuhan anak. Pemenuhan gizi untuk anak sebaiknya dilakukan tidak hanya sejak lahir tapi sejak anak masih berada di dalam usia kandungan (Sukamti, 1994). Menurut Kemenkes stunting adalah kondisi gagal tumbuh pada tubuh dan otak akibat kekurangan gizi dalam waktu yang lama. Sehingga anak lebih pendek dari anak normal seusianya dan memiliki keterhambatan dalam berfikir. Dengan adanya kejadian jelas sekali asupan gizi yang diberikan oleh anak akan mempengaruhi atau berdampak bagi tumbuh kembang anak.

\section{METODE}

Metode yang digunakan dalam penelitian ini adalah deskriptif kuantitatif. Deskriptif kuantitiaf merupakan penelitian yang 
dimaksudkan untuk mengumpulkan informasi mengenai status suatu gejala menurut apa adanya pada saat penelitian dilakukan (Arikunto, 2010).

Penelitian ini dilakukan di Desa Klempun Kecamatan Ngraho Kabupaten Bojonegoro. Jumlah orang yang diwawancara adalah 20 orang dengan ketentuan memiliki anak usia PAUD. Penelitian ini menggunakan pendekatan kuantitatif dengan harapan hasil informasi yang didapatkan dapat diberlakukan secara umum yakni populasi penelitian (Sugiono, 2016). Jadi penelitian dengan metode deskriptif kuantitatif adalah data yang diperoleh dari sampel populasi penelitian dianalisis sesuai dengan metode statistik yang digunakan.

Teknik pengumpulan data yang digunakan dalam peneltian ini adalah angket. Angket adalah teknik pengumpulan data yang dilakukan dengan cara memberi seperangkat pertanyaan tertulis kepada responden untuk dijawabnya (Sugiono, 2016).

Analisis data yang digunakan dalam penelitian ini adalah deskriptif. Analisis deskriptif adalah statistik yang digunakan untuk menganalisis data dengan cara mendeskripsikan atau menggambarkan data yang telah terkumpul sebagaimana adanya tanpa bermaksud membuat kesimpulan yang berlaku untuk umum atau generalis.

\section{HASIL DAN PEMBAHASAN}

Berdasarkan hasil analisis angket yang telah disebarkan kepada responden, didapatkan hasil sebagai berikut:

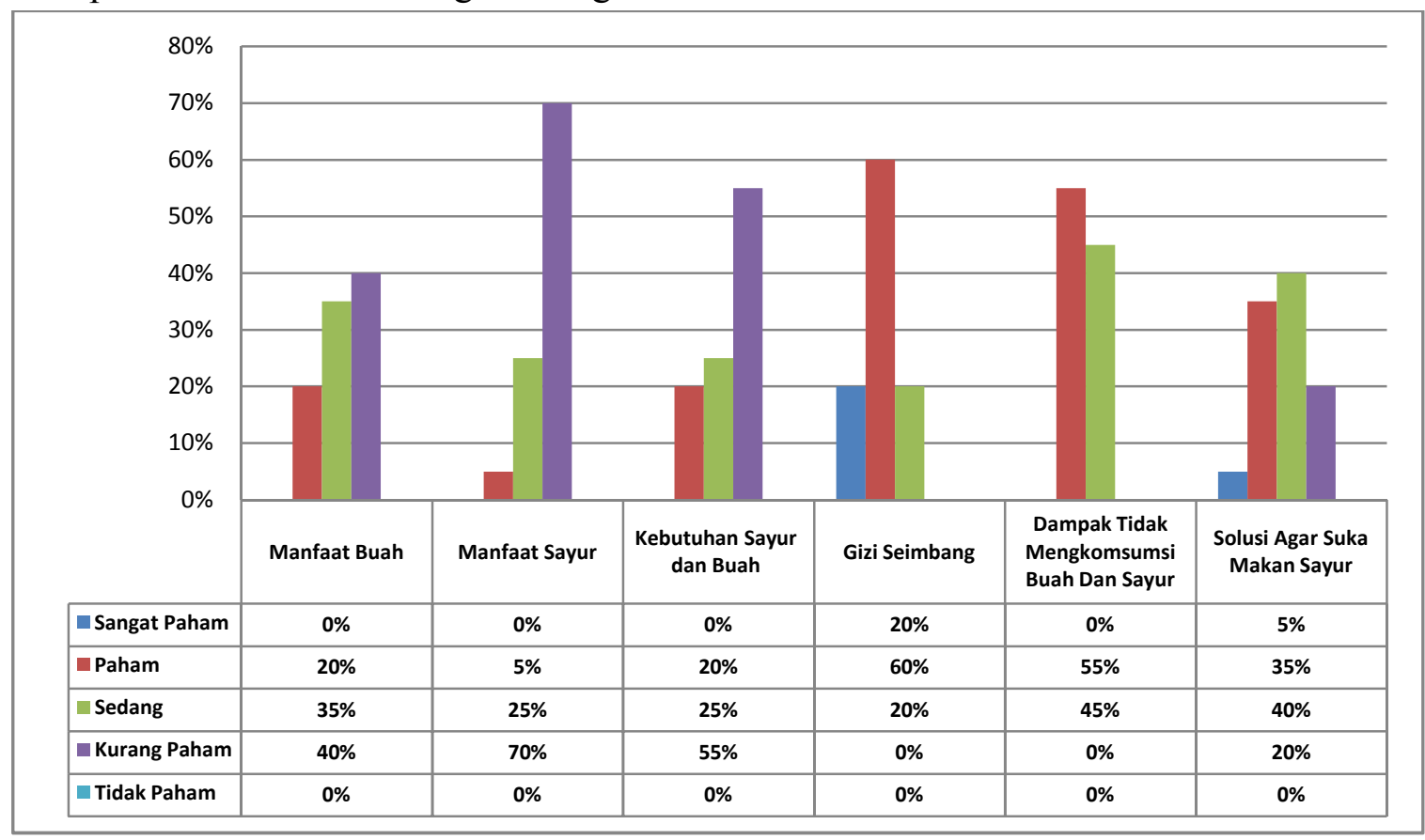

Masyarakat di Desa Klempun Kecamatan Ngraho Kabupaten Bojonegoro menyatakan bahwa tingkat pemahaman manfaat buah adalah dalam kategori paham sebanyak 20\%, pada kategori sedang sebanyak 35\% dan kurang paham sebanyak $40 \%$. Selanjutnya orang tua di Desa Klempun Kecamatan Ngraho Kabupaten Bojonegoro yang memahami manfaat sayur pada kategori paham sebanyak 5\%, pada kategori sedang 
sebanyak $25 \%$, dan kategori kurang paham sebanyak $70 \%$. Pemahaman orang tua tentang kebutuhan sayur dan buah untuk anak masuk dalam kategori paham sebanyak $20 \%$, sebanyak $25 \%$ masuk pada kategori sedang, dan 55\% masuk pada kategori kurang paham.

Berdasarkan penelitian yang telah dilakukan di Desa Klempun Kecamatan Ngraho Kabupaten memahami tentang gizi seimbang yang baik untuk anak menyatakan bahwa sebanyak 20\% menyatakan sangat paham, $60 \%$ menyatakan paham, dan sebanyak $20 \%$ menyatakan kurang paham mengenai konsep gizi seimbang. Berdasarkan penelitian yang sudah dilakukan di Desa Klempun Kecamatan Ngraho Kabupaten Bojonegoro mengenai dampak bagi anak yang tidak mengkomsumsi buah dan sayur yakni sebanyak 55\% menyatakan paham serta $45 \%$ masuk pada kategori sedang. Berdasarkan penelitian menyatakan bahwa pemahaman orang tua tentang solusi agar anak suka makan sayur dalam kategori sangat paham sebanyak 5\%, sebanyak 35\% masuk pada kategori paham, 40\% masuk pada kategori sedang, serta $20 \%$ menyatakan kurang paham.

Berdasarkan penelitian yang dilakukan pemahaman orang tua terhadap manfaat buah termasuk dalam kategori sedang, dan ini sejalan dengan penelitian sayuran dan buah beserta manfaatnya bagi kesehatan yang menerangkan buah dan sayur merupakan bahan pangan yang sangat memberi manfaat bagi tubuh terutama untuk mendukung akan kebutuhan vitamin, vitamin merupakan kelompok senyawa organik yang tidak termasuk dalam golongan protein, karbohidrat maupun lemak (Budiyono, 2004). Berdasarkan penelitian yang telah kami lakukan pemahaman orang tua terhadap manfaat sayur menyatatakan dalam kategori kurang paham,hal ini dikuatkan dengan penelitian sayuran dan buah beserta manfaatnya bagi kesehatan yang menerangkan buah dan sayur merupakan bahan pangan yang sangat memberi manfaat bagi tubuh terutamauntuk mendukung akan kebutuhan vitamin,vitamin merupakan kelompok senyawa organik yang tidak termasuk dalamgolongan protein,karbohidrat maupun lemak (Budiyono, 2004). Setelah penelitian ini dilakukan pemahaman orang tua tentang kebutuhan sayur dan buah untuk anak masuk dalam kategori kurang paham, dan ini sejalan dengan penelitian peran ibu sebagai edukator dan konsumsi sayur buah pada anak yang menerangkan bahwa konsumsi sayur dan buah pada anak usia sekolah masih tergolong rendah dan belum memenuhi anjuran WHO sebesar $400 \mathrm{gr} /$ hari. Berdasarkan penelitian yang telah dilakukan pemahaman orang tua terhadap gizi seimbang masuk dalam kategori paham, hal ini dikuatkan dengan penelitian peningkatan pemahaman gizi seimbang pada anak melalui kegitan membentuk kreasi makanan di kelompok TK B Darul Ulum Ngembalrejo Kecamatan Bae Kabupaten Kudus, yang menerangkan bahwa menu simbang adalah menu yang terdiri dari beraneka ragam makanan dengan jumlah dan proporsi yang sesuai, sehingga memenuhi kebutuhan gizi seseorang guna pemeliharaan dan perbaikan sel-sel tubuh (Rahmawati, 2013). Berdasarkan penelitian yang dilakukan dampak bagi anak yang tidak mengkomsumsi buah dan sayur masuk dalam kategori paham, hal sejalan dengan penelitian Perilaku Konsumsi Sayur dan Anak Prasekolah di Desa Embatau Kecamatan Tikala Kabupaten Toraja Utara yang menyatakan bahwa kurangnya 
konsumsi sayur dan buah dapat menyembabkan tubuh kekurangan nutrisi sehingga dapat menghambat masa pertumbuhan anak khususnya usia pra sekolah (Indira, 2016). Setelah dilakukan penelitian ini pemahaman orang tua mengenai solusi agar anak suka makan sayur menyatakan dalam kategori sedang, dan hal ini dikuatkan dengan penelitian peningkatan motivasi anak makan sayuran melalui metode bermain permainan cooking class pada anak usia 5-6 tahun, yang menyatakan bahwa pentingnya meningkatkan motivasi anak untuk makan sayuran pada anak sejak usia dini, permainan cooking class merupakan salah satu upaya yang dapat dilakukan, adapun cara yang dapat dilakukan dengan cara anak diajak langsung dalam kegiatan memasak sayuran (Wahyuni et al., 2014).

\section{PENUTUP}

\section{Simpulan}

Berdasarkan hasil penelitian yang telah dilakukan dan analisis data angket maka secara umum dapat disimpulkan bahwa pemahaman gizi oleh orang tua di Pos PAUD Tangkas Desa Klempun Kecamatan Ngeraho Kabupaten Bojonegoro mayoritas $50 \%$ dari 20 orang yang dianalisis termasuk dalam kategori sedang. Pentingnya wawasan pengetahuan orang tua akan kebutuhan gizi anak sangat diperlukan,misalnya pengetahuan akan manfaat buah dan sayur, gizi yang dibutukan oleh anak dalam per harinya, pengetahuan gizi seimbang, dampak bagi anak yang tidak mengkomsusmsi buah dan sayur serta solusi agar anak suka makan sayur dan buah.

\section{Saran}

Berdasarkan penelitian yang sudah laksanakan maka peneliti dapat memberikan saran bahwa 1) sebaiknya perlu diadakan parenting class dengan materi kebutuhan gizi anak usia dini untuk meningkatkan wawasan pengetauan orang tua wali murid akan kebutuhan gizi anak. 2) sebaiknya pihak lembaga membuat kerjasama bersama ahlinya misalnya ahli gizi atau bidan setempat untuk memberikan pengarahan terhadap orang tua atau wali murid. 3) pendidik atau lembaga harus ikut serta ikut serta dalam memperatikan gizi anak didiknya, dan bukan orang tua saja yang berperan penting terhadap anak.

\section{DAFTAR PUSTAKA}

Almatsier, s. (2002). Prinsip Dasar Ilmu Gizi. Badan Litbangkes - Kemenerian Kesehatan RI. http://r2kn.litbang.kemkes.go.id:8080 /handle/123456789/77351

Arikunto, S. (2010). Prosedur Penelitian. Rineka Cipta.

Budiyono, M. A. K. (2004). Dasar-dasar ilmu Gizi. Universitas Muhammadiyah Malang.

Indira, I. A. (2016). Perilaku Konsumsi Sayur Dan Buah Anak Prasekolah Di Desa Embatau Kecamatan Tikala Kabupaten Toraja Utara. Media Kesehatan Masyarakat Indonesia, 11(4), 253-262.

Laksono, B. A., Supriyono, \& Wahyuni, S. (2019). Tinjauan Literasi Finansial dan Digital pada Tingkat Ketahanan Keluarga Pekerja Migran Indonesia. Jurnal Penelitian Kesejahteraan Sosial, 18(2), 123-134.

Pratiwi, H. L., \& VAV, S. (2014). Hubungan Asupan Energi dan Protein dengan Status Gizi Anak 1-5 Tahun di Posyandu Lestari IV Desa Kalipucangwetan Kecamatan Welahan Kabupaten Jepara. Universitas Dian Nuswantoro.

Rahmawati, D. (2013). Peningkatkan Pemahaman Gizi Seimbang Pada Anak Melalui Kegiatan Membentuk 
Kreasi Makanan Di Kelompok B Tk Darul Ulum Ngembalrejo Kecamatan Bae Kabupaten Kudus. Universitas Negeri Semarang.

Sugiono. (2016). Metode Penelitian Kuantitatif, Kualitatif, dan $R \& D$. Alfabeta.

Sukamti, E. R. (1994). Pengaruh Gizi Terhadap Pertumbuhan Dan Perkembangan Anak. Cakrawala Pendidikan, 3(November), 139-153.

Wahyuni, T., M. Syukri, \& Halida. (2014).

Peningkatan Motivasi Anak Makan Sayuran Melalui Metode Bermain Permainan Cooking Class Pada Anak Usia 5-6 Tahun. Jurnal Pendidikan Dan Pembelajaran Khatulistiwa, 3(8). 